UDK 349.6:341.231.14

Review article

\title{
STANDING IN ENVIRONMENTAL LAW AFTER URGENDA, JULIANA AND COVID-19 CRISES: WHO SHOULD FORCE GOVERNMENTS TO ACT IN ENVIRONMENTAL ISSUES RELATED TO CLIMATE CHANGE?*
}

\author{
Mirjana Drenovak-Ivanović, PhD, Associate Professor \\ University of Belgrade, Belgrade, Serbia, \\ Faculty of Law,Department of Public Law \\ Bulevar kralja Aleksandra 76, 11000 Belgrade, Serbia \\ mirjana.drenovak@ius.bg.ac.rs
}

\begin{abstract}
Teaching environmental law and climate change issues one may open a number of questions on relations between environmental protection, governmental duties and public rights, starting with: has a government duty to care and maintain a dissent environment and stable climate conditions?; what is a ground for governmental decision-making on actions threatening sustainability of the climate conditions?; where is the beginning and the end of the responsibility of an individual or of an country? The article outlines the elements that provide the criteria under which one may discus on whether it should be the court to force the government to act or should it be a parliament to set laws initiating actions to protect citizens and their human rights from irreversible climate change? The article points out the recent cases State of the Netherlands $v$. Urgenda Foundation (court decision from December 2019) and Kelsey Cascadia Rose Juliana v. USA (court decision from January 2020). In Urgenda, the court concerned questions: whether the Netherlands is obliged to reduce the emission of greenhouse gases from its soil by at least 25\% by the end of 2020 compared to 1990, whether the court can order the State to do so and whether the government is bound to protect human rights in climate crisis? In Juliana, a group of children between the ages of eight and nineteen filed suit against the federal government, claiming that the government violated their constitutional rights by causing dangerous carbon dioxide concentrations. Although the court had found the injury and evidence on causation between government's actions and climate crisis, it found a lack of redressability. The aim of the article is to examine if the concepts of European Green Deal presented on January 2019 by the Von der Leyen Commission to enshrine the 2050 climate neutrality target into life are in line with conclusions from analysed cases and lessons learned from COVID-19 crisis.
\end{abstract}

The paper is result of research activities under Jean Monnet Chair in European Environmental Law organized with the support of the Erasmus+ Programme of the European Union 
Keywords: Individual rights to enforce climate protection, Government's commitments to tackle the climate crisis, State of the Netherlands v. Urgenda Foundation (December 2019), Kelsey Cascadia Rose Juliana v. USA (January 2020), Duty to care and human rights obligation, Illegality of the third runway at Heathrow airport over climate change (February 2020), European Green Deal, COVID-19 crisis and climate crisis

\section{INTRODUCTION}

In the days of uncertainty regarding the health, economic and social consequences of the spread of the SARS-CoV-2 virus, a need arises to draw a parallel between the actual catastrophic consequences of climate change and the more drastic ones predicted by scientists. The first question that comes up is how do societies determine which public interest should have an overriding character, especially having in mind the incidence of influenza pandemics. Sometimes the consequences are less visible and sometimes they are more apparent. Thus, for example, the 1957-1958 influenza pandemic took 116,000 lives in the USA alone. ${ }^{1}$ Ten years later, in 1968, an another influenza pandemic took about 100,000 lives in the US. ${ }^{2}$ Following SARS pandemic in 2003 , the scientists suggested that a massive spread of viruses within the same family can be expected in the coming decades. Consequences of decisions made by a particular state in matters of importance for the spread of various types of viruses are global. The same goes for the impact of any of the states on climate change: defining the percentage of greenhouse gases (GHG) emission reduction, adhering to commitments issuing from international agreements, taking measures at a national level to reduce emissions but also to eliminate the already occurring effects of climate change of one state on all other states. Another question then arises as to whether the states are restricted by the international law or weighing interests is solely within their competence? The first binding international agreement debated under the auspices of the World Health Organization, to link environmental conditions and human health, is the UNECE Protocol on Strategic Environmental Assessment to the Espoo Convention (Kiev, 2003). ${ }^{3}$ The starting point of Parties to the Protocol was the need and importance of strengthening international cooperation in assessing transboundary effects on the environment, including health. The Protocol also regulates the obligation of the state emitting GHG and activities that may have a significant transboundary effect on the environment and health, to inform all potentially affected states,

Viboud, C. et al., Global mortality impact of the 1957-1959 influenza pandemic, The Journal of infectious diseases, vol. 213, no. 5, 2016, pp. 738-745

2 Jester, B.J.; Uyeki, T.M.; Jernigan, D.B., Fifty Years of Influenza A (H3N2) Following the Pandemic of 1968, American Journal of Public Health, vol. 110, no. 5, 2020, pp. 669-676

3 Law on ratification of the SEA Protocol to the Convention on Environmental Impact Assessment in a Transboundary Context, "Official Gazette of the RS“- International contracts, no. 1/2010 
before adopting any plan or program, about the planned activities and include them in the process by hearing their comments. For decades, environmental law has considered legal mechanisms that provide criteria for determining how states should act in a legal issue of a global nature. This has led to the introduction of certain principles and changes in procedures with an environmental element in domestic law. One of basic principles comes from the Rio Declaration on Environment and Development (1992). The Principle 2 of the Rio Declaration has introduced a significant restriction on the discretion of states, by requiring that states exercise their sovereign right to exploit resources only in accordance with their own environmental policies and only to the point where such activities do not cause damage to the environment of other states. The additional obligations of states established by Principle 15 (precaution) and Principle 18 (notification of emergencies) introduce the criteria that states must take into consideration when exercising discretionary power in environmental and climate change decisionmaking or an area of public health.

The third question refers to the degree of certainty of impact on human health and the environment? According to European Environment Agency's data from 2017, at least 10,000 people per year in Serbia do not reach the expected age because they breathe excessively polluted air. The World Health Organization's report on the impact of ambient air on human health in Serbia estimates that in 2016 the exposure to polluted air caused 6,592 deaths and 131,183 lost years of life as a result of air pollution. ${ }^{4}$ The total health cost of polluted air in Serbia amounts to around 1.7 billion euros. ${ }^{5}$ It is estimated that globally 4.2 million people died prematurely that year due to exposure to polluted air. ${ }^{6}$ Member States' health costs were also estimated. ${ }^{7}$ A study by the World Health Organization has found that the financial cost of air pollution in Europe stands more than US\$ 1.6 trillion, which is about a tenth of the European GDP. ${ }^{8}$ Analyses also show that air quality

4 Republic of Serbia, Ministry of Health., Belgrade 2019. Health impact of ambient air pollution in Serbia, p. vii., [http://www.euro.who.int/_data/assets/pdf_file/0020/412742/Health-impact-pollution-Serbia.pdf?ua=1], accessed 15. April 2020

5 Matković Puljić, V., et al., Hronično zagađenje ugljem, 2019, p. 12, [https://www.env-health.org/ wp-content/uploads/2019/03/Chronic-Coal-Pollution-report_SRB.pdf], accessed 15. April 2020

6 Dechezleprêtre, A.; Rivers, N.; Stadler, B., The economic cost of air pollution: Evidence from Europe, 2019, p. 44

7 European Environmental Agency. Damage costs of air pollution from industrial facilities in Europe., [https://www.eea.europa.eu/data-and-maps/data/revealing-the-costs-of-air/damage-costs-of-air-pollution], accessed 15. April 2020

8 World Health Organization, 2015. Air pollution costs European economies US\$ 1.6 trillion a year in diseases and deaths. [http://www.euro.who.int/en/media-centre/sections/press-releases/2015/04/airpollution-costs-european-economies-us\$-1.6-trillion-a-year-in-diseases-and-deaths,-new-who-studysays], accessed 15. April 2020 
improvements explain 15\% of GDP growth in Europe over this period. ${ }^{9}$ With the introduction of the Green Deal and ambitious climate goals by 2050, the EU should reduce the health system expenditures by 200 billion euros each year. Therefore, the annual costs and death toll are familiar. There are still no estimates for other parts of the world, but scientists leading the US administration's fight estimated the virus could kill between 100,000 and 240,000 Americans. ${ }^{10}$ At the same time, scientific analyses show that around 200,000 Americans lost their lives because of air pollution each year even when pollution levels are in line with US Environmental Protection Agencyss guidelines. ${ }^{11}$ The analyses also point to a clear link between areas exposed to polluted air and the risk of death. Scientists from Harvard School of Public Health "TH Chan" found that an increase in only one microgram per meter of PM2.5 particles was associated with a 15 percent increase in coronavirus mortality rates. ${ }^{12}$ This shows that those who are most vulnerable due to exposure to poor air quality and climate change effects are at greatest risk of death from COVID-19 as well. Measures aimed to prevent the spread of the coronavirus resulted in 3.3 million filing for jobless claims already. ${ }^{13}$ The number of employees in the coal industry, who would be directly affected by the transition to renewable energy sources, is many times lower, but although the number of deaths is constant and recurring year by year, globally, we scarcely come across government decisions applying the same approach to reduce GHG emissions (for example European Green Deal or Danish "green reboot"). ${ }^{14}$

9 Dechezleprêtre; Rivers; Stadler, op. cit., note 6, p. 7

10 Buckley, S., et al., published on 31 March 2020. White House Project Grim Toll From Coronavirus. The New York Times. [https://www.nytimes.com/2020/03/31/world/coronavirus-live-news-updates. html], accessed 15. April 2020

11 Bowe, B. et al., Burden of Cause-Specific Mortality Associated With PM2. 5 Air Pollution in the United States, JAMA network open, vol. 2, no. 11, 2019, pp. e1915834-e1915834

12 Xiao Wu et al., published 6 April 2020. Air pollution linked with higher COVID-19 death rates. Harvard T.H. Chan., [https://www.hsph.harvard.edu/news/hsph-in-the-news/air-pollution-linkedwith-higher-covid-19-death-rates/], accessed 15. April 2020

13 Casselman, B.; Cohen, P.; Hsu, T., published on 26 March 2020, 'It's a Wreck': 3.3 Million File Unemployment Claims as Economy Comes Apart, The New York Times, [https://www.nytimes.com/2020/03/26/ business/economy/coronavirus-unemployment-claims.html], accessed 15. April 2020

14 See: Report on the comprehensive economic policy response to the COVID-19 pandemic, Council of the EU, 09/04/2020, 21. Roadmap for Recovery. Work is ongoing on a broader Roadmap and an Action Plan to support the recovery of the European economy through high quality job creation and reforms to strengthen resilience and competitiveness, in line with a sustainable growth strategy. Preconditions for a stable and efficiently functioning of national economy and their impact on real GDP growth after the global recession of 2008 may provide the base for that strategy. Ivanović, V.; Stanišić, N., Monetary freedom and economic growth in new European Union member states, Economic research, vol. 30 , no. 1,2017 , pp. 453-463 
Pointing out the outstanding legal issues both regarding the implementation of measures to prevent the further spread of the COVID-19 and the implementation of measures to prevent climate change, as well as facing the consequences in both cases, indicates a large number of outstanding issues that cannot be solved solely on state level. ${ }^{15}$ At the same time, it also indicates that the states as well as the development of individuals' rights to protect themselves from climate change are those with the key role in finding an effective legal framework to decelerate climate change or other global challenges. This study is outlined in five parts. To start with, in section II, the basis for the right to legal remedy in climate change cases, we point to the recent cases State of the Netherlands v. Urgenda Foundation (court decision from December 2019) and Kelsey Cascadia Rose Juliana v. USA (court decision from January 2020) in which states took different positions on who, on whose behalf, under what conditions has a standing to initiate the rights protection proceedings that may be threatened by climate change. Next, in section III, obligation of the state to fulfil not only commitments following the international agreements but to go beyond is examined and new approaches in the Juliana case and Urgenda case are zoomed in. Bearing in mind that climate change poses an existential threat with irreversible and devastating consequences to people and that governments throughout the world exercising discretionary power may drive the climate change process past the point of no return, in section IV European Green Deal to enshrine the 2050 climate neutrality target into life and lessons learned from Urgenda and Juliana are analysed. In the final section V the findings are summarised.

\section{THE BASIS FOR THE RIGHT TO LEGAL REMEDY IN CLIMATE CHANGE CASES}

\subsection{Occurrence of damage directly attributable to activities of GHG emission operators as basis for imposition of provisional measures in administrative procedure}

In practice of the German Administrative Court, we come across a series of actions taken in order to determine liability for damages based on a share of the largest GHG emitters in contributing to climate change. One of the cases that provides a starting point for further analysis is the case of Lliuya $v$. RWE AG, tried by the Administrative Court of Germany. ${ }^{16}$ In November 2015, Mr Saúl Luciano Lliuya, a farmer living near the Peruvian lake of Huaraz, in a lawsuit filed with

\footnotetext{
15 Bronin, S.C., What the Pandemic Can Teach Climate Attorneys, Stanford Law Review Online, vol. 72, 2020

16 Landgericht Essen, Urt. v. 15.12.2016, Az.: 2 O 285/15
} 
the Administrative Court, requested imposition of provisional measures aiming to prohibit further activities of RWE, one of Germany's largest electricity producers, and indemnity for damage caused by climate change. In the lawsuit it is stated that RWE contributed to climate change by emitting large amounts of GHG, and, as a consequence, should take responsibility for melting of mountain glaciers near the city of Huaraz. The melting of the glaciers led to a rise in the nearby lake level, which urged the residents of this city to take a number of measures in order to mitigate the effects of climate change related to flood protection. Taking into account the contribution of RWE to climate change, the plaintiff requested indemnity of $0.47 \%$ of the cost from the company. In this case, the Administrative Court held that the causal link between the GHG emissions from RWE and the effects of climate change related to the melting of glaciers in Peru cannot be established. It is further stated that taking into account the cumulative liability of all pollutants for climate change does not lead to a different decision, given that no single pollutant, even a considerable one such as RWE, has a decisive impact on climate change. ${ }^{17}$ The court rejected the request for determining provisional measures and the claim for damages, arguing that a contrary decision would not represent an effective legal remedy given that even a complete and permanent suspension of the RWE operation would not put an end to the melting of the glacier.

The possibility of indemnity for environmental damage is regulated identically in European Union law. The Environmental Liability Directive 2004/35/EC reads as early as in its introductory section that not all environmental damage can be eliminated. The mechanism of legal protection of the environment from damage can only be activated if the damage is concrete and quantifiable and if a causal link can be established between the damage and one or more pollutants. Therefore, Directive 2004/35/EC can only be applied in cases with established liability for environmental damage caused by diffuse pollution, only if it is possible to determine the causal link between the damage and the activity of the particular operator. ${ }^{18}$ Does this mean that the argument that other operators and individuals contribute to climate change through their activities may deprive them of the possibility of indemnity for damage caused by climate change? Does this mean that for the largest pollutants, for which the amount of annual emissions can be determined, that amount can be used in order to apply the polluter pays principle, thereby ensuring indemnity for caused by climate change, where the value would depend on its share of total GHG emissions? In addition to the obligation to comply with the rules governing trade in these emissions, operators emitting GHG would also have

17 See Zahar, A., Mediated versus Cumulative Environmental Damage and the International Law Association's Legal Principles on Climate Change, Climate Law, vol. 4, no. 3-4, 2014, pp. 217-233

18 The Environmental Liability Directive 2004/35/EC, OJ L 143, 30.4.2004, p. 56-75, Art. 4(5) 
an additional obligation which would possibly affect finding alternative options. However, this raises an additional question: who and at what point is responsible for merging development policies with climate change?

It is possible to answer this question by analysing cases before administrative court which decided on the activities of operators that may contribute to climate change. The origin of this idea in comparative law is found in the practice of the Supreme Court of New Zealand ${ }^{19}$ In that case, the Court, in deciding on the appeal against the decision of the Environment Court granting a permit to engage in mining activities, also considered whether the administrative authority making the decision on granting permit for activities that may contribute to climate change (in this case the Environment Court has the jurisdiction for issuing administrative acts which decide on granting permits), is required to consider the effects of the proposed activities on climate change? ${ }^{20}$ The Court held that the governing body may have such an obligation, but only after adopting a separate act on New Zealand's National Environmental Standards. Such an act is necessary because it would provide a code for aligning environmental, climate and other policies. Without predefined benchmarks, policy alignment would not be consistent. In other words, it could occur that in the same circumstances preference is given to different public interests.

The most recent example found in the UK jurisprudence implies that the Paris Agreement temperature goal has binding effect and must be integrated in each decision that could jeopardise that goal. ${ }^{21}$ British NGOs Friends of Earth and Plan B Earth filed a suit against the Secretary of State for Transport alleging that the climate change impacts related to the expansion of Heathrow airport were not considered adequately. Assessing the actions of government and Paris agreement commitments, the Appeal court ruled plans for a third runway at Heathrow airport illegal as the government's commitments to tackle the climate crisis had not been taken into account by the ministers. The Appeal court stressed that the commitment to the Paris Agreement made by the Government is a document that confirms Governmental policy in climate change. In the decision, the court also points out the relationship between the Paris Agreement and the Parties' activities in implementing GHG reduction measures: the decision-maker, in this case the Secretary, is obliged ,,to take the Paris Agreement into account when arriving at his decision (...) it does not follow from this that the Secretary of State was

19 The High Court of New Zealand Christchurch Registry, CIV 2012-409-000972 [2012] NZHC 2156

20 See Mayer, B., The applicability of the principle of prevention to climate change: A response to Zahar, Climate Law, vol. 5, no. 1, 2015, pp. 1-24

21 Court of Appeals on appeal from the Queen's Bench Division Divisional Court Lord Justice Hickinbottom, Mr Justice Holgate and Mr Justice[2020] EWCA Civ 214, 27 February 2020 
obliged to act in accordance with the Paris Agreement or to reach any particular outcome". ${ }^{22}$ This, it appears, introduces an additional dilemma: what does it mean to take the Paris Agreement into account, if not to assess whether the decision contributes to achieving GHG reduction in accordance with the obligations of a particular state arising from that agreement or not? The decision-maker is required to determine how the Paris Agreement affects the substance of the decision and to determine whether a positive law (Climate Change Act in the UK) sets objectives that differ from those set out in the Paris Agreement.

\subsection{Violation of basic human rights caused by climate change, preventing the occurrence of irreversible consequences, preventing further damage and protecting future generations as a basis for deciding on state liability for climate change damage: New approaches in the Urgenda case}

Analysing cases led before the European Court of Human Rights (ECtHR) has not brought us to any decisions that point to additional elements of associating basic human rights with the consequences of climate change. ${ }^{23}$ The 2009 UN Human Rights Commissioner's Report indicates that the specific nature of climate change makes it impossible to associate their consequences with violations of basic human rights, firstly because "there is no way of establishing a causal link between climate change and the contribution of a particular state", and also because "climate change leads to profound consequences along with natural disasters and other forms of environmental degradation." ${ }^{24}$

In recent practice of the Dutch Court of Appeal and Supreme Court, we come across a case that links basis for imposition of provisional measures on operators or determining state's liability for breach of the obligation to prevent further damage caused by climate change to violations of basic human rights, most importantly the violation of Article 2 (protecting the right to life) and Article 8 (right to private and family life) of the European Convention for the Protection of Human Rights and Fundamental Freedoms (ECHR). ${ }^{25}$

$22 \quad$ Ibid., par. 238

23 Drenovak-Ivanović, M., Human rights obligations related to climate change. Legal life, 2017, pp. 226242

24 OHCHR, Report of the Office of the United Nations High Commissioner for Human Rights on the Relationship Between Climate Change and Human Rights, U.N. Doc. A/HRCl 10/61, 2009, para. 70

25 Climate Case Urgenda, Hoge Raad, 20-12-2019, ECLI:NL:HR:2019:2007, 19/00135. [https://www. urgenda.nl/wp-content/uploads/ENG-Dutch-Supreme-Court-Urgenda-v-Netherlands-20-12-2019. pdf], accessed 15. April 2020. Convention for the Protection of Human Rights and Fundamental Freedoms, ETS No.005, into force from 3 September 1953. See Krstić, I.; Cučković, B., Procedural aspects of article 8 of the ECHR in environmental cases: The greening of human rights law, Annals of the Faculty of Law in Belgrade, vol. 63, no. 3, 2015, pp. 170-189 
In a case initiated upon a complaint filed by 900 citizens of the Netherlands and the Environmental Organization against the Dutch Government, it was argued that the negligent attitude towards climate change, as noted in strategic documents and legal framework developed during the 5 years before the lawsuit, augments the contribution of the Netherlands to climate change and exceeding global warming limit. ${ }^{26}$ Referring to the reports and analyses presented during the proceedings, the Court decided that the state had done little to prevent climate change, and that the measures proposed to be implemented by 2030 and beyond could not compensate for the actions due as early as possible. ${ }^{27}$ An analysis is provided as an example, showing that urgent application of the measures defined for the post -2030 period would result in a reduction of $28 \%$ of GHG emissions by the end of $2020 .{ }^{28}$ In a unanimous decision by a three-member panel, the Hague District Court stated that it is the Government's duty to care for citizens and protect citizens from potential climate change hazards and ordered a reduction in GHG emissions in the Netherlands for at least $25 \%$ by $2020 .{ }^{29}$ The explanation indicates that the fulfilment of obligations assumed from international agreements does not relieve the state from the responsibility to protect citizens by taking additional reduction measures that go beyond obligations under international agreements. ${ }^{30}$ The reasoning provides a retrospection, reminding that, by 2011, the Netherlands had an obligation to reduce GHG emissions by $30 \%$ by 2020 , and the abandonment of these goals was not explained by any scientifically based arguments or analysis (para. 52).

The Urgenda case represents a significant precedent that links the jurisprudence of the ECtHR to climate change for the first time. The Court of Appeal states that the state is encouraged to take measures to prevent damage as much as possible,

26 Rechtbank Den Haag, 24-06-2015, C/09/456689 / HA ZA 13-1396. Lin, J., The first successful climate negligence case: A comment on Urgenda foundation $v$. the state of The Netherlands (Ministry of Infrastructure and the Environment), Climate Law, vol. 5, no. 1, 2015, pp. 65-81; De Graaf, K.J.; Jans, J.H., The Urgenda decision: Netherlands Liable for role in causing dangerous global climate change, Journal of Environmental Law, vol. 27, no. 3, 2015, pp. 517-527

27 Climate Case Urgenda, Hoge Raad, 20-12-2019, ECLI:NL:HR:2019:2007, 19/00135, pars. 70-73

28 Ibid., para. 47

29 "This duty of care entails that in 2020, the Netherlands must achieve a reduction in greenhouse gas emissions of $25 \%-40 \%$ in comparison to emissions in 1990 . A reduction of this magnitude is necessary to have any hope of achieving the $2^{\circ} \mathrm{C}$ target. This is also the most cost-effective option. (...) the State has a duty of care to take mitigating measures...”, (para. 49); “... The Court of Appeal is of the opinion that a reduction obligation of at least $25 \%$ by the end of 2020 , as ordered by the District Court, is in line with the State's duty of care (para. 53)." Climate Case Urgenda, Parket bij de Hoge Raad, 1309-2019, ECLI:NL:HR:2019:1026, [https://uitspraken.rechtspraak.nl/inziendocument?id=ECLI:NL:PHR:2019:1026], accessed 15. April 2020

30 Drenovak-Ivanović, M., Impact of Environmental Acquis and Chapter 27 Negotiations on the Development of Climate Change Rights in Serbia, Legal life, 2018, pp. 335-350 
whenever the government has knowledge and reports on existence of real and imminent danger. ${ }^{31}$ Since climate change is a dangerous threat that can lead to loss of life and violation of the right to family life, it is an obligation of the state to protect the rights contained in Articles 2 and 8 from industrial activities that may violate these basic human rights. Particular consideration was given to the possibility to include in a complaint the protection of victims outside the jurisdiction of the ECHR, as well as to protect the rights of future generations. ${ }^{32}$ In deciding on this issue, a key role was given to the objective of the Court's decision. According to the Court of Appeal, it protects the rights of current generations, not exclusively the rights of younger generations, since they already face the consequences of climate change, which they will continue to encounter throughout their lives if GHG are not effectively reduced globally. ${ }^{33}$

The analysis of Urgenda case leads to several conclusions. First, the ECHR and ECtHR jurisprudence provide the basis for individuals' rights to enforce climate action of states. ${ }^{34}$ Secondly, the protection of basic human rights cannot point to the definition of the obligation of the state by applying duty of care, but is determined on the basis of the GHG reduction targets established to help reaching goals defined by the scientists' positions and the Paris Agreement..$^{35}$ Thirdly, it is the obligation of the state to reduce but also to ensure the reduction of GHG which means that the state has a positive obligation to start reduction efforts at the earliest possible stage. It also raises some important questions that determine the further development of individual rights to enforce climate protection: is the

31 Climate Case Urgenda, Parket bij de Hoge Raad, 13-09-2019, ECLI:NL:HR:2019:1026, para. 45 [https://uitspraken.rechtspraak.nl/inziendocument?id=ECLI:NL:PHR:2019:1026], accessed 15. April 2020; Verschuuren, J., The State of the Netherlands v Urgenda Foundation: The Hague Court of Appeal upholds judgment requiring the Netherlands to further reduce its greenhouse gas emissions, Review of European, Comparative \& International Environmental Law, vol. 28, no. 1, 2019, pp. 94-98

32 Leijten, I., Human rights v. Insufficient climate action: The Urgenda case, Netherlands Quarterly of Human Rights, vol. 37, no. 2, 2019, pp. 112-118

33 Climate Case Urgenda, Parket bij de Hoge Raad, 13-09-2019, ECLI:NL:HR:2019:1026, para. 3738, [https://uitspraken.rechtspraak.nl/inziendocument?id=ECLI:NL:PHR:2019:1026], accessed 15. April 2020

34 Winter, G., Armando Carvalho and Others v. EU: Invoking Human Rights and the Paris Agreement for Better Climate Protection Legislation, Transnational Environmental Law, vol. 9, no. 1, 2020, pp. 137164

35 Minnerop, P., Integrating the 'duty of careunder the European Convention on Human Rights and the science and law of climate change: the decision of The Hague Court of Appeal in the Urgenda case, Journal of Energy \& Natural Resources Law, vol. 37, no. 2, 2019, pp. 149-179; Wegener, L., Can the Paris Agreement Help Climate Change Litigation and Vice Versa?, Transnational Environmental Law, vol. 9, no. 1, 2020, pp. 17-36 
court competent to compel the government to act, ${ }^{36}$ or the legislator has a final say in making decisions on reducing GHG emissions and adapting to the effects of climate change? Calling upon the human rights protection cleared the way for the Court of Appeals in Urgenda to reject the state's reliance on the system of separation of powers. ${ }^{37}$ However, this also raises the question of how such a decision, if made by a court, can be acted upon.

\section{SHOULD THE STATE FULFIL ONLY THE OBLIGATIONS ISSUING FROM INTERNATIONAL AGREEMENTS OR DO MORE: NEW APPROACHES IN THE JULIANA CASE}

Among the key issues in establishing climate change rights is: does absence of having a critical role in causing climate change absolve the operator of responsibility for the consequences of climate change; does the fact that even without the operation of one operator GHGs that accelerate climate change would continue to be produced stultifies imposition of provisional measures to ban one operator; does the fact that one state cannot prevent climate change by itself also means that domestic courts should not act in cases involving the determination of the state's responsibility for implementing measures or determining the policy that does not lead to climate change mitigation?

In the Urgenda case the Court of Appeal clearly stressed that even if there was no complete scientific certainty regarding the effectiveness of the reduction order it does not entitle the state to refrain from taking further measures. ${ }^{38} \mathrm{But}$, is it the court that should order that? The first case in the US to consider this issue and legal standing in climate legal actions was Massachusetts v. EPA. ${ }^{39}$ The Supreme Court unambiguously confirmed that EPA can regulate GHG, such as carbon dioxide , as "air pollutant" under the Clean Air Act that should mitigate the consequences of climate change despite the fact that climate change has a global nature. ${ }^{40}$

In Juliana case (Youths' Climate Case), a group of children between the ages of eight and nineteen filed suit against the federal government, asserting that it vio-

36 Burgers, L., Should Judges Make Climate Change Law?, Transnational Environmental Law, vol. 9, no. 1, 2020, pp. 55

37 The Court of Appeal held that measures were called for because the state was violating human rights, and that the reduction order imposed on the state allowed it sufficient room to choose how it would comply with that order. Climate Case Urgenda, Parket bij de Hoge Raad, 13-09-2019, ECLI:NL:HR:2019:1026, para. 67, [https://uitspraken.rechtspraak.nl/inziendocument?id=ECLI:NL:PHR:2019:1026], accessed 15. April 2020

$38 \quad$ Ibid., para. 63

39 Massachusetts v. EPA, 549 U.S. 497 (2007)

40 Massachusetts v. EPA, [https://www.justice.gov/enrd/massachusetts-v-epa], accessed 15. April 2020 
lated their constitutional rights by causing dangerous carbon dioxide concentrations. The plaintiffs asked the Supreme Court to order the government to act on climate change. ${ }^{41}$ The court found a concrete injury and evidence on causation. It was 2-1 decision by which the court found a lack of redressability because the issues presented in Juliana were beyond the power of the court to remedy. In other words, the court held that reaching a decision which would request from the Government to make a plan to "phase out fossil fuel emissions and drag down excess atmospheric CO2" is not within the jurisdiction of the court. Such a decision should be made by "the political branches or to the electorate at large, the latter of which can change the composition of the political branches through the ballot box". ${ }^{42}$ Dissenting Judge Staton stressed "(...) the injury at issue is not climate change writ large; it is climate change beyond the threshold point of no return. (...) practical redressability is not measured by our ability to stop climate change in its tracks and immediately undo the injuries that plaintiffs suffer today-an admittedly tall order; it is instead measured by our ability to curb by some meaningful degree what the record shows to be an otherwise inevitable march to the point of no return. As we approach that threshold, the significance of every emissions reduction is magnified. (...)". ${ }^{43}$

The analysis of Juliana case leads to several conclusions. Both the reasoning of the decision and the reasoning in the dissenting opinion indicate that there is evidence that the federal government had been promoting the use of fossil fuels for years despite reports showing ,that it can cause catastrophic climate change, and that failure to change existing policy may hasten an environmental apocalypse". ${ }^{44}$ This is the first case in the US that clearly presents the existence of the climate crisis, points to evidence that unambiguously confirms it, and to the need to urgently find measures to reduce GHG emissions. What has been left undone is an analysis of arguments that would provide the court, in a system of separation of powers, with certain jurisdictions in cases that reasonably indicate that there was a dramatic risk of harm and passing the point of no return. If the Supreme Court considers that it does not have jurisdiction to oblige the Government to adopt the relevant act of precisely defined content, could the Government be

$41 \quad$ Juliana v. United States, no. 18-36082 (9th Cir. 2020)

42 Julianav. United States, p. 32, [https://cdn.ca9.uscourts.gov/datastore/opinions/2020/01/17/18-36082. pdf], accessed 15. April 2020. See: Parenteau, P., End Game for the Kids Climate Case?, published on 29 January 2020, [http://vjel.vermontlaw.edu/end-game-kids-climate-case/], accessed 15. April 2020

43 Julianav. United States, p. 45, [https://cdn.ca9.uscourts.gov/datastore/opinions/2020/01/17/18-36082. pdf], accessed 15. April 2020

44 Julianav. United States, p. 11, [https://cdn.ca9.uscourts.gov/datastore/opinions/2020/01/17/18-36082. pdf], accessed 15. April 2020. See Gundlach, J., Climate risks are becoming legal liabilities for the energy sector, Nature Energy, vol. 5, no. 2, 2020, pp. 94-97 
obligated to some other enactment? We believe that the court could have at least requested continued cooperation at international level in the fight against climate change and further compliance with the obligations under the Paris Agreement and future climate agreements. Following the previously analysed decision on the third runway at Heathrow airport, we conclude that the court could also point to the obligation of decision-makers to take the Paris Agreement into account when preparing the decision.

\section{EUROPEAN GREEN DEAL TO ENSHRINE THE 2050 CLIMATE NEUTRALITY TARGET INTO LIFE AND LESSONS LEARNED FROM URGENDA AND JULIANA}

The European Green Deal is a roadmap aimed to point out the most important steps to make Europe the first climate-neutral continent by $2050 .{ }^{45}$ European Climate $\mathrm{Law}^{46}$ should be the cornerstone that would frame turnover of the political commitments into a legal obligation. Under Charter of Fundamental Rights of the European Union, high level of environmental protection in accordance with the principle of sustainable development is guaranteed by Article $37 .{ }^{47}$ However, the proposal of the European Climate Law does not further specify the link between the violation suffered by individuals, which could jeopardise their human rights, including the right to a high level of environmental protection.

By analysing the proposal of European Climate Law, we conclude that the new Article 11, which introduces a multilevel climate and energy dialogue, can be the basis for further development of climate change rights. The newly proposed Article would oblige Member States to introduce a dialogue, in the format customary in the law of a Member State, that would, as a result, enable a dialogue between local government, civil society, economic and investor representatives and the general public on whether the EU is meeting climate-neutrality objectives. ${ }^{48}$ The dialogue would also be led, by the same stakeholders, on different scenarios for the development of energy and climate change policies. If we compare the proposed measures

45 European Commission. Communication from the Commission to the European Parliament, the European Council, the Council, the European Economic and Social Committee and the Committee of the Regions, The European Green Deal. Brussels, 11.12.2019 COM(2019) 640 final; Haines, A.; Scheelbeek, P., European Green Deal: a major opportunity for health improvement, The Lancet, 2020

46 European Commission. Proposal for a Regulation of the European Parliament and the Council establishing the framework for achieving climate neutrality and amending Regulation (EU) 2018/1999 (European Climate Law), Brussels, 4.3.2020 COM(2020) 80 final 2020/0036 (COD)

47 Charter of Fundamental Rights of the European Union, OJ C 326, 26.10.2012, p. 391

48 Hilson, C., Hitting the Target? Analysing the Use of Targets in Climate Law, Journal of Environmental Law, 2020 
with the positive law of the Member States, or with Serbian positive law, we can see that this is a strategic environmental impact assessment procedure. The EU has not gone beyond what was already provided for under existing law. The essence of further development of legal mechanisms guaranteeing the reduction of GHG emissions and adaptation to climate change, which is an obligation established by the proposed European Climate Law in Art. 2 and Art. 4, is the development of climate change rights at Member State level. The central place, in fact, seems to be the adaptation of the legal system, which has to find the basis for applying traditional legal norms to new social relations that emerge from the rapid rise of climate change impact. Member States' legal systems should also make it possible for the transition to the new climate neutrality goals to be just and inclusive, leaving no one behind. The analysed cases of Urgenda and Juliana indicate that the most important task in achieving such a transition is to find the basis, ${ }^{49}$ within the legal systems of the Member States, ${ }^{50}$ to turn the objectives of achieving climate neutrality and the goals of the European Green Deal into concrete individual rights to enforce climate protection. The criteria for these actions should have been included in the proposed European Climate Law.

\section{CONCLUDING OBSERVATIONS}

Climate change and the consequences of the spread of COVID-19 are crisis situations with significant impacts on sustainability and security. The decisions of the governing bodies, courts, strategic documents and proposals for climate change law indicate the extent to which measures to fight climate change and measures to adapt to climate change are taken into account in decision-making. Judge Staton started her powerful dissent in Juliana comparing the emergency of climate change situation with "an asteroid barrelling toward Earth" and Judge Hurwitz, explaining the decision and writing for the majority, stressed that the plaintiffs presented in Juliana ,compelling evidence that climate change has brought ... eve of destruction ... nearer." Although an individual operator is not the only contributor to climate change, nor is any state for that matter, it does not entitle the state to refrain from taking further measures. The Urgenda case indicated that a state has a duty to care and that the obligation to reduce GHG emissions urgently is in line with its human rights obligation. This means, firstly, that a state has an

49 Fisher, L., Challenges for the EU Climate Change Regime, German Law Journal, vol. 21, no. 1, 2020, pp. 5-9

50 Lukic, M., Relevance of conceptualizing the relationship between international and national law for the legal nature of the European Union, Archibald Reiss Days, 2015, pp. 331-339; See European Commission. Proposal for Regulation of the European Parliament and the Council establishing the Just Transition Fund. Brussels, 14.01.2020 COM(2020) 22 final 2020/0006 (COD) 
obligation to cooperate with other states at the international level in the fight against climate change, and to fulfil its obligations under the Paris Agreement and future climate agreements. Second, a state has an obligation to develop a climate change policy that is aligned with the objectives issuing from the Paris Agreement. Such policy should contain clear guidelines for integrating climate change interests into policy development in other areas, as well as criteria for weighing overriding interests when more than one public interest is involved, one of which is climate. Third, duty to care means that a state has an obligation to take into account the violation of basic human rights due to climate change. Fourth, a state has an obligation to turn the objectives of the fight against climate change into concrete individual rights to enforce climate protection. Those conclusions could be universal and applicable in other jurisdictions.

Responses to the crisis caused by the expansion of COVID-19 demonstrate that societies can find both economic and industrial potential to overcome current challenges in the state of emergency. ${ }^{51}$ Climate change is not uncertain and it requires identical activities from the states. Initiatives for such activities can already be found in the recommendations of the leading political parties and business associations in Denmark who requested a "green reboot" that puts green growth as a base of the recovery from the coronavirus crisis. ${ }^{52}$ In March 2020, the Heads of States and Governments invited the Commission to use Green Deal and its Investment Plan as a base for comprehensive EU recovery plan integrating the green transition to push forward to boost green recovery and just transition after COVID-19.53

\section{REFERENCES}

\section{BOOKS AND ARTICLES}

1. Bowe, B. et al., Burden of Cause-Specific Mortality Associated With PM2. 5 Air Pollution in the United States, JAMA network open, vol. 2, no. 11, 2019, pp. e1915834-e1915834

51 Czarnezki, J.J. Lessons from the climate and COVID-19 crises, The Hill, published on 9 April 2020, [https://thehill.com/opinion/energy-environment/491964-lessons-from-the-climate-and-covid-19-crises], accessed 15. April 2020

52 EU urged to bring building 'renovation wave' into recovery plan, Euractive, published on 7 April 2020, [https://www.euractiv.com/section/energy/news/eu-urged-to-bring-building-renovation-waveinto-recovery-plan/], accessed 15. April 2020

53 European Green Deal must be central to a resilient recovery after Covid-19, published on 9 April 2020, [https://www.climatechangenews.com/2020/04/09/european-green-deal-must-central-resilient-recovery-covid-19/?fbclid=IwAR01S769fvDv6hXTfVY13j8xGtsQTNzaD4Ie60pp1EMLswPe44txaRssLNI], accessed 15. April 2020 
2. Bronin, S.C., What the Pandemic Can Teach Climate Attorneys, Stanford Law Review Online, vol. 72, 2020

3. Burgers, L., Should Judges Make Climate Change Law?, Transnational Environmental Law, vol. 9, no. 1, 2020, pp. 55

4. De Graaf, K.J.; Jans, J.H., The Urgenda decision: Netherlands Liable for role in causing dangerous global climate change, Journal of Environmental Law, vol. 27, no. 3, 2015, pp. 517-527

5. Dechezleprêtre, A.; Rivers, N.; Stadler, B., The economic cost of air pollution: Evidence from Europe, 2019

6. Drenovak-Ivanović, M., Human rights obligations related to climate change, Legal life, 2017, pp. 226-242

7. Drenovak-Ivanović, M., Impact of Environmental Acquis and Chapter 27 Negotiations on the Development of Climate Change Rights in Serbia, Legal life, 2018, pp. 335-350

8. Fisher, L., Challenges for the EU Climate Change Regime, German Law Journal, vol. 21, no. 1, 2020, pp. 5-9

9. Gundlach, J., Climate risks are becoming legal liabilities for the energy sector, Nature Energy, vol. 5, no. 2, 2020, pp. 94-97

10. Haines, A.; Scheelbeek, P., European Green Deal: a major opportunity for health improvement, The Lancet, 2020, pp. 1327-1329

11. Hilson, C., Hitting the Target? Analysing the Use of Targets in Climate Law, Journal of Environmental Law, 2020, pp. 195-220.

12. Ivanović, V.; Stanišić, N., Monetary freedom and economic growth in new European Union member states, Economic research-Ekonomska istraživanja, vol. 30, no. 1, 2017, pp. 453-463

13. Jester, B.J.; Uyeki, T.M.; Jernigan, D.B., Fifty Years of Influenza A (H3N2) Following the Pandemic of 1968, American Journal of Public Health, vol. 110, no. 5, 2020, pp. 669-676

14. Krstić, I.; Čučković, B., Procedural aspects of article 8 of the ECHR in environmental cases: The greening of human rights law, Annals of the Faculty of Law in Belgrade, vol. 63, no. 3, 2015, pp. 170-189

15. Leijten, I., Human rights v. Insufficient climate action: The Urgenda case, Netherlands Quarterly of Human Rights, vol. 37, no. 2, 2019, pp. 112-118

16. Lin, J., The first successful climate negligence case: A comment on Urgenda foundation $v$ the state of The Netherlands (Ministry of Infrastructure and the Environment), Climate Law, vol. 5, no. 1, 2015, pp. 65-81

17. Lukic, M., Relevance of conceptualizing the relationship between international and national law for the legal nature of the European Union, Archibald Reiss Days, 2015, pp. 331-339

18. Mayer, B., The applicability of the principle of prevention to climate change: A response to Zahar, Climate Law, vol. 5, no. 1, 2015, pp. 1-24

19. Minnerop, P., Integrating the 'duty of care'under the European Convention on Human Rights and the science and law of climate change: the decision of The Hague Court of Appeal in the Urgenda case, Journal of Energy \& Natural Resources Law, vol. 37, no. 2, 2019, pp. 149-179

20. OHCHR, Report of the Office of the United Nations High Commissioner for Human Rights on the Relationship Between Climate Change and Human Rights, U.N. Doc. A/HRC/ 10/61, 2009 
21. Verschuuren, J., The State of the Netherlands $v$ Urgenda Foundation: The Hague Court of Appeal upholds judgment requiring the Netherlands to further reduce its greenhouse gas emissions, Review of European, Comparative \& International Environmental Law, vol. 28, no. 1, 2019, pp. 94-98

22. Viboud, C., et al., Global mortality impact of the 1957-1959 influenza pandemic, The Journal of infectious diseases, vol. 213, no. 5, 2016, pp. 738-745

23. Wegener, L., Can the Paris Agreement Help Climate Change Litigation and Vice Versa?, Transnational Environmental Law, vol. 9, no. 1, 2020, pp. 17-36

24. Winter, G., Armando Carvalho and Others v. EU: Invoking Human Rights and the Paris Agreement for Better Climate Protection Legislation, Transnational Environmental Law, vol. 9, no. 1, 2020, pp. 137-164

25. Zahar, A., Mediated versus Cumulative Environmental Damage and the International Law Association's Legal Principles on Climate Change, Climate Law, vol. 4, no. 3-4, 2014, pp. 217-233

\section{EU LAW}

1. Charter of Fundamental Rights of the European Union, OJ C 326, 26.10.2012, p. 391

2. European Commission. Communication from the Commission to the European Parliament, the European Council, the Council, the European Economic and Social Committee and the Committee of the Regions, The European Green Deal. Brussels, 11.12.2019 $\operatorname{COM}(2019) 640$ final

3. European Commission. Proposal for a Regulation of the European Parliament and the Council establishing the framework for achieving climate neutrality and amending Regulation (EU) 2018/1999 (European Climate Law), Brussels, 4.3.2020 COM(2020) 80 final 2020/0036 (COD)

4. European Commission. Proposal for Regulation of the European Parliament and the Council establishing the Just Transition Fund. Brussels, 14.01.2020 $\operatorname{COM(2020)} 22$ final 2020/0006 (COD)

5. Report on the comprehensive economic policy response to the COVID-19 pandemic, Council of the EU, 09/04/2020, 21. Roadmap for Recovery.

6. The Environmental Liability Directive 2004/35/EC, OJ L 143, 30.4.2004

\section{LIST OF NATIONAL REGULATIONS, ACTS AND COURT DECISIONS}

1. Climate Case Urgenda, Hoge Raad, 20-12-2019, ECLI:NL:HR:2019:2007, 19/00135

2. Court of Appeals on appeal from the Queen's Bench Division Divisional Court Lord Justice Hickinbottom, Mr Justice Holgate and Mr Justice[2020] EWCA Civ 214, 27 February 2020

3. Landgericht Essen, Urt. v. 15.12.2016, Az.: 2 O 285/15 


\section{WEBSITE REFERENCES}

1. Buckley, S., et al., published on 31 March 2020. White House Project Grim Toll From Coronavirus, The New York Times, [https:/www.nytimes.com/2020/03/31/world/coronavirus-live-news-updates.html], accessed 15. April 2020

2. Casselman, B.; Cohen, P.; Hsu, T., published on 26 March 2020. 'It's a Wreck': 3.3 Million File Unemployment Claims as Economy Comes Apart. The New York Times, [https:/www. nytimes.com/2020/03/26/business/economy/coronavirus-unemployment-claims.html], accessed 15. April 2020

3. Climate Case Urgenda, Hoge Raad, 20-12-2019, ECLI:NL:HR:2019:2007, 19/00135, [https://www.urgenda.nl/wp-content/uploads/ENG-Dutch-Supreme-Court-Urgenda-vNetherlands-20-12-2019.pdf], accessed 15. April 2020

4. Euractive. EU urged to bring building 'renovation wave' into recovery plan, published on 7 April 2020, [https://www.euractiv.com/section/energy/news/eu-urged-to-bring-buildingrenovation-wave-into-recovery-plan/], accessed 15. April 2020

5. European Environmental Agency. Damage costs of air pollution from industrial facilities in Europe., [https://www.eea.europa.eu/data-and-maps/data/revealing-the-costs-of-air/damage-costs-of-air-pollution], accessed 15. April 2020

6. European Green Deal must be central to a resilient recovery after COVID-19, published on 9 April 2020, [https://www.climatechangenews.com/2020/04/09/european-green-dealmust-central-resilient-recovery-covid-19/?fbclid=IwAR01S769fvDv6hXTfVY13j8xGtsQT NzaD4Ie60pp1EMLswPe44txaRssLNI], accessed 15. April 2020

7. Jason J. Czarnezki, Lessons from the climate and COVID-19 crises, The Hill, published on 9 April 2020, [https://thehill.com/opinion/energy-environment/491964-lessons-from-theclimate-and-covid-19-crises], accessed 15. April 2020

8. Juliana v. United States, [https://cdn.ca9.uscourts.gov/datastore/opinions/2020/01/17/1836082.pdf], accessed 15. April 2020

9. Matković Puljić, V., et al., 2019. Hronično zagađenje ugljem, p. 12. available at: [https:// www.env-health.org/wp-content/uploads/2019/03/Chronic-Coal-Pollution-report_SRB. pdf], accessed 15. April 2020

10. Parenteau, P., End Game for the Kids Climate Case?, 29 January 2020, [http://vjel.vermontlaw.edu/end-game-kids-climate-case/], accessed 15. April 2020

11. Republic of Serbia, Ministry of Health., Belgrade 2019. Health impact of ambient air pollution in Serbia, [http://www.euro.who.int/_data/assets/pdf_file/0020/412742/Healthimpact-pollution-Serbia.pdf?ua=1], accessed 15. April 2020

12. World Health Organization, 2015, Air pollution costs European economies US\$ 1.6 trillion a year in diseases and deaths, [http://www.euro.who.int/en/media-centre/sections/press-releases/2015/04/air-pollution-costs-european-economies-us\$-1.6-trillion-a-year-in-diseasesand-deaths,-new-who-study-says], accessed 15. April 2020

13. Xiao Wu et al., published 6 April 2020, Air pollution linked with higher COVID-19 death rates. Harvard T.H. Chan., [https://www.hsph.harvard.edu/news/hsph-in-the-news/air-pollution-linked-with-higher-covid-19-death-rates/], accessed 15. April 2020 